\title{
Voices of fire
}

\section{Sinai imagery in Acts 2 and rabbinic midrash}

\author{
Theresa Abell Haynes
}

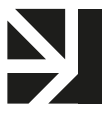

VERTAISARVIOITU

KOLLEGIALT GRANSKAD

PEER-REVIEWED

www.tsv.fi/tunnus

DOI: https://doi.org/10.30752/nj.102389

Aвstract - Early followers of Jesus and later rabbinical Jews, two divergent branches of Judaism emerging respectively from the Second Temple and Post-Second Temple eras, both drew upon the cultural memory of Sinai to establish their identity. This article examines how the author of Acts used the Sinai imagery of theophanic fire in the Pentecost narrative of Acts 2 to reinforce a continuation of Judaism and offer an inclusive expansion of it to gentile believers. Then it looks at how later rabbinic sources used Sinai images of fire and multiple languages to reinforce the authority of the Torah and their exclusive identity within the Sinai relationship.

\section{Introduction}

When the rabbis visualised the encounter on Mount Sinai, the crucial moment in Jewish history when God spoke directly to Israel and gave them Torah, they saw fire (Deut. 5:4, 5, $22,23,24,25,26)$. The mountain burned with fire, but more importantly, God's voice itself manifested as fire, flames of fire (Mekilta Bahodesh 9). And even more remarkably, as this voice emerged into the air, it was heard and understood in multiple languages (Sifre \$343 F395.7-I3, F399.II-I5; Exodus Rabbah 5:9). ${ }^{1}$

When the author of Acts described the day of Pentecost, the crucial moment in Christian history when the Holy Spirit came down from heaven and filled the Jewish followers of Jesus, he wrote about a great wind, tongues of fire and God's message being miraculously spoken and understood in multiple languages (Acts 2:I-II).

1 The image of God's voice appearing as fire can be found in Targumic expansions as well (e.g. Targum Neofiti Exod 20:2).
What is intriguing about this parallel is that the Hebrew Bible does not explicitly say that God's voice at Sinai appeared as fire or was audible in multiple languages (Exodus I 9:16, 20:18). Neither does Acts 2, in which the day of Pentecost is described, explicitly mention Exodus or the revelation on Sinai. In fact, previous generations of biblical scholars have emphasised that Acts is a book primarily written for gentile Christian believers, not Jewish believers (Keener 201 2: 402), and have even argued that Pentecost, also known in Hebrew as Shavuot, was initially a harvest festival in the Hebrew Bible and only became a Sinai commemoration in later generations. ${ }^{2}$

2 The first rabbinical mention of Pentecost as an 'anniversary of the giving of the law on Sinai' was from Jose ben Halafta, c. I $50 \mathrm{CE}$ (Seder 'Olam Rabbah 5) (Bruce I 990: I I4). However, a growing number of scholars think the association was made much earlier. For a detailed treatment of this connection see Sejin Park's published dissertation Pentecost and Sinai: The Festival of Weeks as a Celebration of the Sinai Event (Park 2008). 
This brings up many questions. When did the Jewish tradition of God's voice being visible as fire and audible in multiple languages develop? Was it possible that Luke, the presumable author of Acts, ${ }^{3}$ knew of these traditions and had them in mind when he wrote the description of the Holy Spirit's arrival? Was he intentionally drawing a connection between Sinai and the Pentecost event? And if so, were later rabbinic authors who described God's voice as being visible as flames of fire and audible in multiple languages simply recording Jewish traditions that had developed earlier, or were they responding to the claims of the Jesus Movement?

These questions are complicated by the ambiguous relationship between oral traditions and written record. While the earliest midrashim describing God's voice as fire are thought to have been redacted in the third century, ${ }^{4}$ the ideas included in these written works are likely to be older, as evidenced by Philo of Alexandria's first-century writings. Acts, on the other hand, was probably written in the second half of the first century by an author who may or may not have been aware of Jewish traditions. ${ }^{5}$

3 Early church fathers unanimously regard the book of Acts as being written by Luke (Bruce I990: 2, 3), a remarkable fact considering Luke was not otherwise prominent in tradition and not a likely candidate for a pseudonym (Keener 20I 2: 4I 2).

4 Mekbilta de-Rabbi Ishmael and the Sifre to Deuteronomy, redacted in the second half of the third century (Ben-Eliyahu et al. 20I3: $63-5,72-4)$.

5 Scholars disagree on an exact date for Acts, ranging between the 6os and mid-second century, with a majority of scholars holding a centrist view between the 7 os and mid80s (Keener 201 2: 392). In general I agree with Keener, who argues for a date close to 70, citing Lukan authorship evidenced by the 'we' passages, correspondence between Acts and first-century historical events that reflect early memory and Pauline apologet-
However, in this article I argue that Luke was most likely aware of orally circulating Jewish traditions concerning God's voice appearing visibly as fire, and I examine how and why he may have drawn on Sinai imagery to communicate his message. I then look at later rabbinic commentaries on the Sinai experience, and consider how and why they used images of God's voice appearing as fire and being audible in multiple languages. To do this I begin by looking generally at Sinai in Jewish literature. Then, for context on orally circulating Jewish Sinai traditions, I turn to Philo's first-century commentaries. I then look at Acts and consider how and why the author included Sinai symbols. Finally, I look at specific rabbinic literature concerning Sinai, focusing on how and why the writers used symbols of fire and multiple languages.

\section{Mount Sinai in Jewish commentary}

For ancient biblical interpreters, the Mount Sinai experience, as recorded in Exodus, was arguably the most significant event of the Hebrew Bible. From this moment forward, God's instructions, the Torah, became the central occupation of Jewish life (Kugel I 997: 373). Rabbis likened it to a marriage contract, one in which Israel was to be 'holy', literally, set apart, קדוש (qadosh). 6

ics that respond to local charges that would have been irrelevant in later years (ibid. p. 384). If we assume the book of Acts was written within the probable lifetime of Luke, a companion of Paul, then the audience would have included a mixture of Jesus-believing Jews, gentiles and 'God fearers' who had participated in synagogue culture (Acts I 8:4).

6 Karin Hedner Zetterholm argues that a good analogy comes from the Jewish marriage ceremony, where the husband says to his bride, 'Behold you are sanctified/separated (qeddushah) for me through this ring' (Zetterholm 201 2: I7-18). 
Exodus 20 records the story of God appearing to Moses on Mount Sinai and his delivering the Ten Commandments. Notably, the Israelite community had already agreed to Yahweh's invitation to covenant before they received the details of the Torah (Exodus I 9:8). It is in this context that Moses delivered the terms of the contract, and Israel accepted the Torah with all of its mandates for national and daily life - everything from dietary restrictions and weekly work cessations to annual feasts and individual moral codes.

Immediately following these Ten Commandments, Exodus pauses in its delivery of legal instructions and narrates, 'When the people saw the thunder and lightning and heard the trumpet and saw the mountain in smoke, they trembled with fear' (Exodus 20:I 8 NIV). While this English translation conveys the sense of overwhelming awe and fear the people experienced, there is something important lost in translation. This phrase translated in many English versions as 'When the people saw the thunder', וכל העם רואים את הקולות, is rendered literally as 'and all the people saw the voices': the Hebrew word הקולות ( הa-qolot), often translated in English as 'thunder', can also be translated as 'voice', or in this case 'voices'. The second object the people saw, הלפידם (ba-lapidim), is also plural and has been translated 'lightning', or 'lightning flashes' (Exodus 20:18). However, this word can literally be translated 'flames' or even 'tongues of fire' (Fraade r 99r: 45; Larsson I 999: I 35; Zetterholm 201 2: I9).

Ancient biblical commentators, who regarded textual inconsistencies as intentional divine clues and an invitation for further investigation (Kugel I997: I-36; Zetterholm 2012: 7I), asked the question of how Israel could 'see' God's voice. What would it look like? Rabbinic commentators came to the conclusion that God's voice appeared

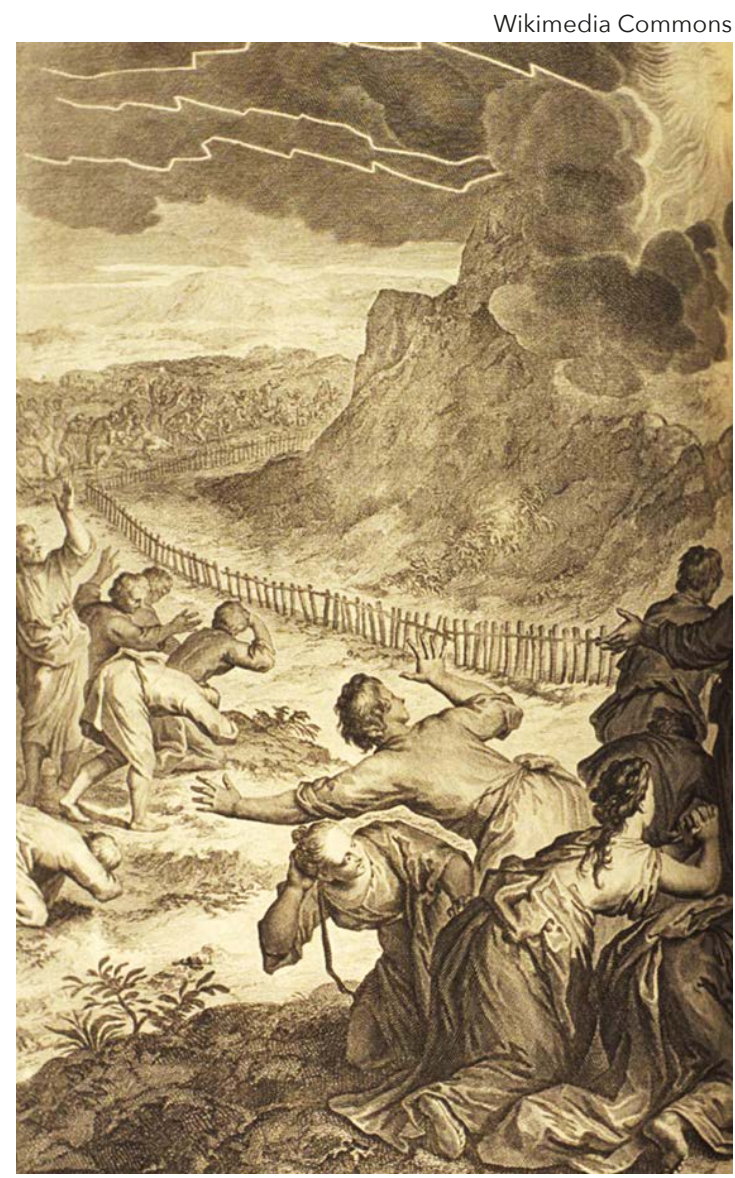

The promulgation of the Law in Mount Sinai, as in Exodus 20:1, 2, 18-21. Illustration from the 1728 Figures de la Bible; illustrated by Gerard Hoet (16481733) and others, and published by P. de Hondt in The Hague. Image courtesy Bizzell Bible Collection, University of Oklahoma Libraries.

as fire (Mekilta Bahodesh 9, Sifre $\$ 343$ F399.I I-I 5).

The earliest rabbinical examples of this concept in rabbinic literature can be found in the Mekbilta de-Rabbi Ishmael and the Sifre to Deuteronomy, both of which were redacted in the second half of the third century (BenEliyahu et al. 201 3: 63-5, 72-4). Even so, the idea seems to pre-date the rabbinic movement. Nearly two centuries earlier, Philo of Alexandria also envisioned God's voice as being like fire. 


\section{Philo}

Philo of Alexandria was a first-century Jewish philosopher of the diaspora, who wrote extensive commentaries on the Torah. Philo's work is especially relevant in this case because his commentaries on the Pentateuch are some of the only ones on the Torah that predate rabbinic writings, and despite not being included in later rabbinic works, they display many similar features and Jewish traditions (Fraade 1991: 7).

Like later rabbis, Philo frequently employed other verses from the Pentateuch to address exegetical questions and problems raised with the original text in question. Philo takes this approach in On the Decalogue, his commentary on Sinai and the Ten Commandments. In addressing the question of how God delivered the 'ten words' to the nation of Israel, he asks ' $\mathrm{Did} \mathrm{He}$ do so by His own utterance in the form of a voice?' (Philo, On the Decalogue 32 [Colson, LCL]).

True to Jewish aversion to anthropomorphisms, Philo argues that God would not have used a common mouth, tongue or windpipes. It had to be something unique, he reasoned.

I should suppose that God wrought on this occasion a miracle of a truly holy kind by bidding an invisible sound to be created in the air more marvelous than all instruments and fitted with perfect harmonies, not soulless, nor yet composed of body and soul like a living creature, but a rational soul full of clearness and distinctness, which giving shape and tension to the air and changing it to flaming fire, sounded forth like a breath through a trumpet an articulate voice so loud that it appeared to be equally audible to the farthest as the nearest. (Philo, On the Decalogue 32-4)
As magnificent as an audible fire sounds, it is not a description that goes far enough for Philo. He continues his narrative, emphasising the clear, communitive power of the voice.

Then from the midst of the fire that streamed from heaven there sounded forth to their utter amazement a voice, for the flame became articulate speech in the language familiar to the audience, and so clearly and distinctly were the words formed by it that they seemed to see rather than hear them. (Philo, On the Decalogue 46)

Philo's description of God's voice being visible as fire could be his own idea, but because Philo often included orally circulating ideas, it probably represents Jewish traditions (VanderKamp 2002: 253).

\section{Acts 2: on the day of Pentecost}

The day of Pentecost, as described in Acts 2, was the watershed moment for the Jesus Movement, with 3,000 people added to the original group of followers on that day, an event described by many Christians as the 'birth' of the Christian church (Acts 2:I4I). These new believers included a sizeable number of diaspora Jews who were present in Jerusalem for the Pentecost celebrations, and who are likely to have seeded the JesusJewish movement outside Jerusalem.

When the day of Pentecost came, they were all together in one place. Suddenly a sound like the blowing of a violent wind came from heaven and filled the whole house where they were sitting. They saw what seemed to be tongues of fire that separate and came to rest on each of them. All of them were filled with the Holy Spirit and began to speak in other languages as the Spirit enabled them. (Acts 2:I -4 NIV) 


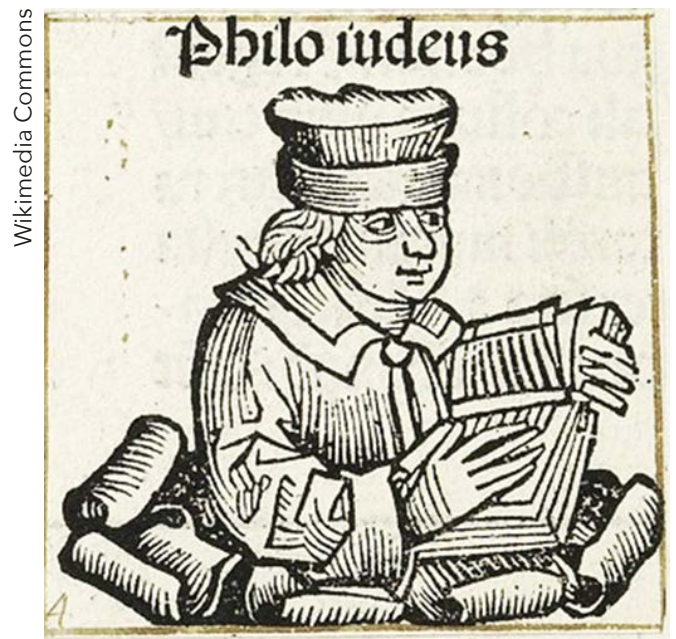

Philo of Alexandria. Unknown author, 1493. Rijksmuseum.

While there is no indication that Luke was influenced by Philo, it is safe to assume that if Philo was familiar with common Jewish traditions, then other first-century Jews living in both the diaspora and Palestine could have been too.

This, of course, also assumes that Luke was Jewish or at least thoroughly familiar with synagogue culture, including Jewish oral traditions, an assumption that has been gaining traction as scholars have largely embraced a more protracted timeline for the 'Parting of Ways'.7

Jacob Jervell argues that Luke's narrative demonstrates a great familiarity with Jewish ideology and values: the prominent role of God as the director of Israel's history and his irresistible will (Jervell I 996: I 24, I9-20: Acts 7:2-53, I $3: 16-25)$, Luke's emphasis on the sin of idolatry (20), 8 the significance

7 See Becker and Reed 2007. For treatment of Luke's writing within a Jewish context, see Oliver 2012.

8 The sin of idolatry is denying the law and its first commandments. Herod is punished for allowing people to hail him as God
Luke places on Israel's scriptures and the prophets (47), the emphasis on Jesus as the Messiah (25-34), and the narratives of Jesus and the apostles adhering to the law (54-6I). In Acts, even the Jesus-believing gentiles accept a provisional version of the law with the Apostolic Decree ( I I 5 ). ${ }^{9}$

Even so, Luke does not explicitly mention Sinai, Moses or the moment when Israel received the Torah. Instead, Luke records Peter quoting the prophet Joel and a messianic Psalm of David. Tying these prophecies together, Peter's speech introduces Jesus as the Messiah and invites the Jews present in the crowd to repent, be baptised and receive the 'gift of the Holy Spirit' (Acts 2:38). The only reference to Sinai is Luke's note that the events occurred on the 'Day of Pentecost' (Acts 2:I).

This reference is problematic as scholars are not united on when Jews began celebrating Pentecost as a commemoration of Sinai (Keener 2012: 787). Pentecost seems to have originally been celebrated as a harvest festival and is not explicitly linked to Sinai in the Hebrew Bible, although scholars such as James C. VanderKam and Sejin Park have argued effectively that as the fulcrum of Jewish history, it surely would have been celebrated annually by the first century (VanderKam 2002: 248; Park 2008: 85-99, 239). ${ }^{10}$ Park demonstrated that other biblical literature outside the Pentateuch, most

(Acts I 5:20). The first point of the Apostolic Decree is that the gentile believers abstain from idolatry (Acts $15: 20$ ).

9 The Apostolic Decree is based on Levitical provisions listed for foreigners living among Israelites (Lev. I 7-18). Thus, even this simplified law for gentile believers is based on Torah.

10 Pentecost as a harvest festival also has implications for Christian theology. See VanderKam 2002; Davis 2009. 
importantly the book of Jubilees, provides ample evidence linking Sinai to Pentecost $(7-82)$. In the narrative of Jubilees, the covenant on Mount Sinai is portrayed as a renewal of earlier covenants between God and humanity. Significantly, this covenant renewal is celebrated on the 15 th day of the third month, the same day assigned to Pentecost in the Hebrew Bible (VanderKam 2002: 24I-2; Park 2008: 99).

However, even without the Acts 2: I reference to Pentecost, the symbolism in the Acts 2 narrative would have evoked Sinai to readers familiar with Jewish tradition and the significance of the day of Pentecost.

\section{Sinai symbols of fire and wind}

It is not surprising that ancient biblical commentators associated God's voice on Sinai with fire. The biblical account of Exodus and the Mount Sinai encounter in the Pentateuch is permeated with images of fire (Exodus I $3: 2$ I-2, 40:34-8).

When Moses and Aaron offered the first public sacrifice in front of the Tabernacle, fire came out of God's presence and consumed the sacrifice (Lev. 9:24). A parallel phenomenon of fire falling from heaven to burn a sacrifice occurred when Solomon dedicated the Temple (2 Chr. 7:I) and when Elijah called upon God to reveal himself to the pagan-leaning Israelites in a fire-calling contest with the prophets of Baal (I Kgs. I 8:22-38). In a full narrative circle, following the fire-falling miracle on Mount Carmel, Elijah ran for his life and found himself at Mount Horeb (Sinai), where God promised to communicate with him. In this story he experienced a powerful wind that shattered rocks, an earthquake and fire. These were all elements of God's presence and speech at Sinai, but the text said that God was not in any of these. Ultimately Elijah heard God's voice in a 'gentle whisper' (1 Kgs. 19:9-13).

In Exodus, after the Israelites arrived at Mount Sinai, Moses instructed them to prepare for the encounter with God (Exodus I 9: Io, I 4). On the morning of the third day he led the community out of the camp, to the foot of the mountain, and they observed that Sinai was on fire. 'Mount Sinai was covered with smoke, because the Lord descended on it in fire. The smoke billowed up from it like smoke from a furnace, the whole mountain trembled violently' (Exodus i 9:I 8 NIV). Then the people heard/saw God's voice deliver the Ten Commandments (Exodus 20:I-I7). And it was terrifying. 'When the people saw the thunder and lightning and heard the trumpet and saw the mountain in smoke, they trembled with fear' (Exodus 20: 8 NIV). They stayed at a distance and asked Moses to mediate.

In Deuteronomy, which continues the narrative forty years after the Mount Sinai revelation, Moses addressed a new generation of Israelites, imploring them to remain faithful to God. He appealed to the Israelites' collective, personal experience with God; 'The Lord spoke to you face to face out of the fire on the mountain' (Deut. 5:4 NIV). ${ }^{11}$

Luke uses this same image of theophanic fire in Acts 2 to validate the Jesus Movement. A few chapters later, in Acts ro when the members of the house of Cornelius (a gentile) accept Peter's message and are baptised, it is the evidence of the Holy Spirit's filling them that convinces the circumcised (Torahobservant Jewish) believers that the gospel message is open to gentiles as well as Jews. Peter uses this experience to argue that the gentiles should be baptised (Acts 10:44-8). Thus, the Holy Spirit, as a gift that is observable to other people, becomes the primary

11 See also Deut. 4:I I, I2, 33, 36; 5:2 2, 24, 26; 9:10; IO:4. 


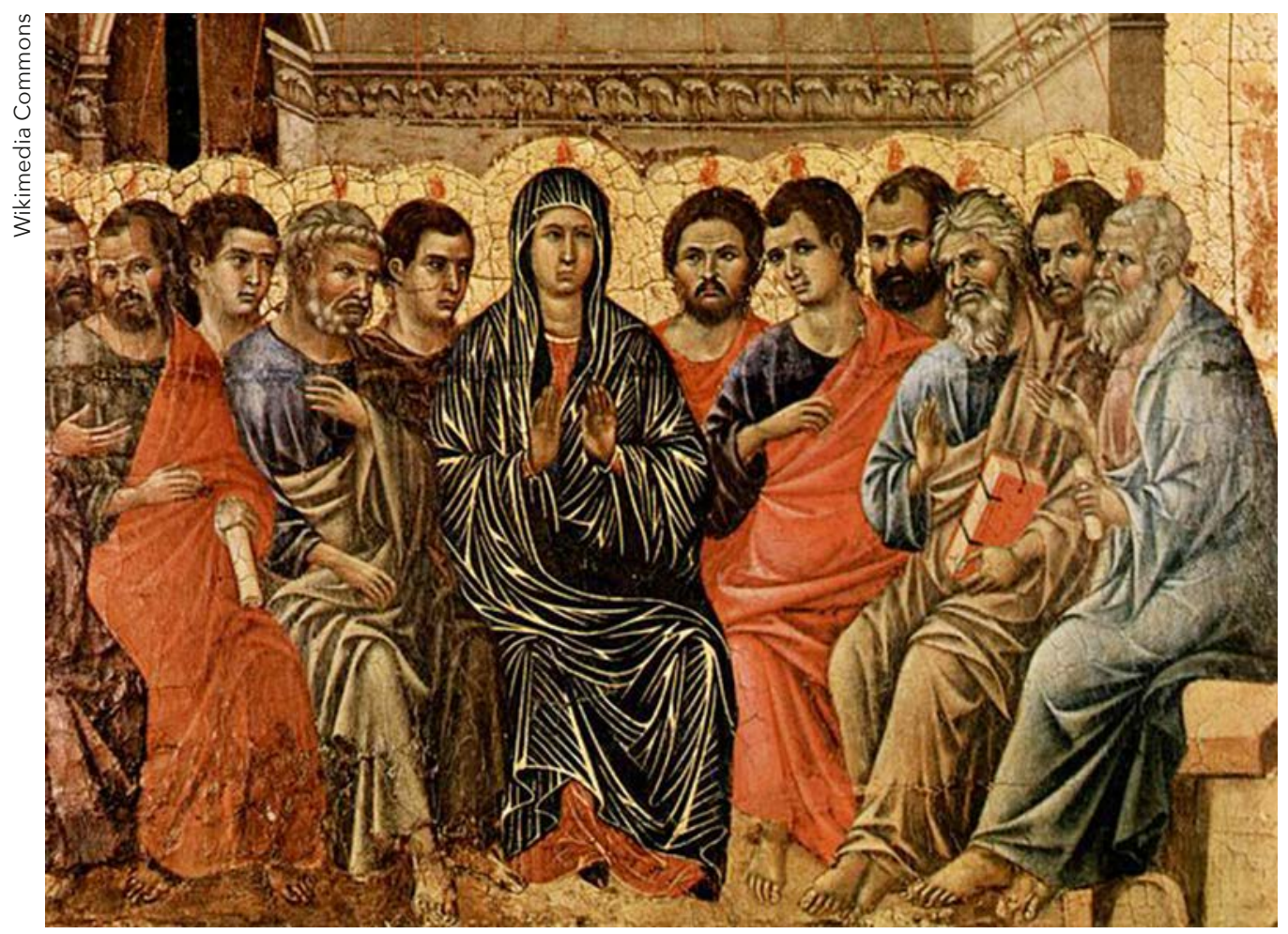

A typical Western image of the Pentecost. Duccio di Buoninsegna, 1308. Museo dell'Opera del Duomo.

identity marker for Jesus believers, uniting both Torah-observant Jews and gentiles. In a parallel of how the Torah, given at Sinai, is the primary identity marker for rabbinic Jews, the Holy Spirit, given on the day of Pentecost, becomes the identity marker, the symbol of the community of Jesus-believers in Acts.

Wind is also a symbol of God's spirit, connected with Sinai (Ps. 29; Heb. I2:18; Josephus, Antiquities III 5:2). Its inclusion in Acts connects it with other theophanies such as Elijah on Mount Horeb (I Kgs. I 9) and Ezekiel's dry bones (Ezek. 37). In fact, the Hebrew word רוח (ruab) and the Greek word $\pi v \varepsilon \tilde{\mu} \mu \alpha$ (рneuma) are used for wind, breath and spirit, combining these theological concepts and images linguistically. ${ }^{12}$

12 Although Christian/Jewish concepts of the Holy Spirit differ, primarily owing to the Christian doctrine of the Trinity, the

\section{Rabbis and their literature}

Rabbinic Judaism emerged in the first millennium as a response to the Temple destruction in $70 \mathrm{CE}$. According to the rabbinical sources themselves, during the time before, and the chaos immediately after the Temple destruction, scribes and Pharisees maintained Torah-observant Judaism by preserving the Torah and recording ancient Jewish traditions and biblical exegesis. These rabbis grew in prominence over the first two centuries, as the Patriarchs began appointing them as judges and religious functionaries. Their writings, including the Mishnah, a collection of legal teaching and exegesis of the Torah, and a further commentary of the Mishnah, the Talmud, became an integral part of the new

spirit of God is a prevalent concept found throughout the Hebrew Bible. 
Jewish identity in the post-Temple period when Temple sacrifice was no longer possible (Hayes 20I I: 90).

This rabbinical account of their story is regarded with more scepticism today by scholars, who regard the second Temple period to be one of great diversity. But despite a lack of objective narrative regarding its establishment, one thing is indisputable: rabbinical Judaism survived to become the dominant expression of Judaism. It also left an enormous literary output, including not only the well-known Mishnah and two Talmuds, but also biblical commentaries known generally as midrash (Hayes 20I I: 20).

Midrash stood out from previous biblical interpretation for its unique format: systematic explanations beginning with a base text and continuing with sub-units of exegetical digression. Chains of comments, attributed to a plurality of rabbinic voices, followed. No single voice or author was credited with mediating scripture alone (Fraade r99 I: I6-I 7). ${ }^{13}$ Two of the earliest midrashim from the Tannaitic period, the Mekbilta de-Rabbi Ishmael and the Sifre to Deuteronomy, include commentaries on the Sinai revelation and the idea of God's voice being visible as fire.

\section{Mekhilta de-Rabbi Ishmael}

\section{And All the People Saw the Thunderings.}

They saw what was visible and heard what was audible. - These are the words of R. Ishmael. R. Akiba says: They saw and heard that which was visible. They saw the fiery word coming out from the mouth

13 Prior to rabbinic midrash, the Qumran community employed a similar systematic approach to biblical exegesis, though they focused primarily on the prophetic books and did not present multiple interpretations (Fraade I991: I6-I7). of the Almighty as it was struck upon the tablets, as it is said: 'The voice of the Lord hewed out flames of fire' (Ps. 29:7).

(Mekilta Bahodesh 9, Lauterbach)

The Mekbilta is a very good example of rabbinical exegesis as it identifies a 'problem' in the text and seeks to reconcile it with the rabbinical understanding of scripture as a whole. In this case, the problem is twofold. First of all, there is the logical problem of people 'seeing' thunder and then there is the question of what they saw.

People typically see lightning and hear thunder. However, in this case the Hebrew ראים (ro-im) is clearly translated 'they saw' and not 'they heard', which would be derived from the root שמעy (shama'), a verb most famously used in the Shema Israel, שמע ישראל (shema' Israel) 'Hear Israel'.

Rabbis assumed that this unexpected verb choice was intentional. So, they sought to explain the miraculous nature of seeing the invisible, and to do that, they found a clue in the text itself. The object of the sentence, what the people saw, הקולת (ba-qolot), has been translated 'the thunderings', but could just as easily have been translated 'the voices', as this word is commonly understood. Therefore, this verse could be read, 'And all the people saw the voices' (Larsson I999: I35; Zetterholm 201 2: I9).

Rabbi Ishmael's first comment sets the conversation in motion by stating what seems obvious, 'They saw what was visible and heard what was audible'. Rabbi Ishmael's statement of the self-evident frames the conversation as a literal interpretation of the narrative. The people literally saw something and they literally heard something.

Rabbi Akiba gently takes it a step further. 'They saw and heard that which was visible', meaning not only did they see something visible and hear something audible, they both 
saw and heard a literal thing which was visible. They saw something that is typically only heard. The thunder or voices was something physically present that the people both saw and heard. So, what was it?

As we have seen, the Deuteronomic account records that the mountain itself was on fire and the Lord spoke from out of the fire (Deut. $5: 4,22-3)$. Later, in Moses' poetic account at the end of Deuteronomy, the text describes a fiery law that came out of God's hand. Rabbi Akiba says, 'They saw the fiery word coming out from the mouth of the Almighty as it was struck upon the tablets, as it is said: "The voice of the Lord hewed out flames of fire"' (Mekilta Bahodesh 9, Lauterbach).

The last sentence of the midrash is a direct quotation from Psalm 29:7, equating God's voice with flames of fire. The word קול $(k o l)$ is used many times in Psalm 29 in reference to God's voice.

\section{Sifre to Deuteronomy}

Sifre to Deuteronomy covers several sections of Deuteronomy including the poetic blessing of Moses found in Deuteronomy 33, just before Moses' death and Israel's subsequent entry into the land of Canaan. Unlike the Exodus passage exegeted by Mekhilta, Deuteronomy 33 is not a direct narrative of Sinai. However, the allusions to Sinai identify the context and frame the many interpretations that follow.

And he said:

The Lord came from Sinai,

And rose from Seir unto them;

He shined forth from mount Paran,

And He came from the myriads holy,

At His right hand was a fiery law unto them. (Deut. 33:2, JPS Tanakh I9I7)14

14 Many English translations obscure the reference to fiery law by translating it differently. The NIV obliterates it altogether,
The Sifre offers several interpretations of this section, including this one.

'Lightning flashing at them from His right' $(33: 2)$. When (each) word would go forth from the mouth of the Holy One, blessed be $\mathrm{He}$, it would go forth from the right side of the Holy one, blessed be He, to the left side of Israel, encircle the camp of Israel twelve miles by twelve miles, and return by the right side of Israel to the left side of the Lord. The Holy One, blessed be He, would receive it in His right hand and engrave it upon the table, His voice would travel from one end of the world to the other, as it is said, 'The voice of the Lord kindles flames of fire' (Ps. 29:7). (Sifre §343 F399. I I-I 5, Fraade)

In the Mekbilta the fire was associated with God's voice. Here, it was associated directly with the Torah, which is also synonymous with the voice of God. This is reinforced by the Psalm 29 reference, 'The voice of the Lord kindles flames of fire'. The Hebrew phrase אש דת (esh-dat), translated 'lightning flashing', or 'fiery law', is a hapax legomenon comprised of two words: fire and law. As the Mekbilta explains, God's voice is both visible and audible; and now the rabbis have taken the connection one step further and linked God's voice, or his Word, to fire, to Torah (Fraade I 99r: 45).

This midrash has an additional element of the fire encircling Israel, separating it from the nations, a theme picked up in the Sifre's other commentaries on this passage.

The Sifre continues with additional parallels between the Torah and fire, including the idea that a person can be both warmed by the words of Torah, but also burned if he should

with the second half of the verse reading 'He came with myriads of holy ones from the south, from his mountain slopes'. 
fall into them, possibly reminding the student that while the Torah is a comfort, it also contains the judgement of God. The next interpretation clarifies this concept. 'Just as fire is used both in this world and in the world to come, so the words of Torah are both in this world and in the world to come' (Sifre, \$343 F399.I I-I 5, Fraade).

\section{Languages of the nations}

In addition to fire, the Sifre's interpretations on Deuteronomy 33:2 include the tradition that God's voice was heard in multiple languages.

[B] Another interpretation: When the Holy One, blessed be He, revealed Himself in order to give the Torah to Israel, he did not speak to them in one language but in four languages, [as it is said,] "He said: The Lord came from Sinai": this is the Hebrew language. "He shone upon them from Seir": this is the Roman language. "He appeared from Mount Paran": this is the Arabic language. "And approached from RibebothKodesh": this is the Aramaic language.

[C] Another interpretation: "He said: The Lord came from Sinai": When the Holy One, blessed be He, revealed Himself in order to give the Torah to Israel, He revealed Himself not just from one direction but from [all] four directions, as it is said, "He said: The Lord came from Sinai; He shone upon them from Seir; He appeared from Mount Paran.” And what is the fourth direction? "God comes from Ternan” (Hab. 3:3). (Sifre §343 F $395 \cdot 7-\mathrm{I} 3$, Fraade)

Between these two interpretations, the rabbis highlight the 'spatial and linguistic' totality of God's self-disclosure (Fraade r 99 I:
3I). In the first interpretation, God's voice, directed at Israel, is heard in four languages, symbolically representing the total number of human languages. In the second interpretation, God approaches from all four directions, surrounding Israel.

\section{Other nations reject the Torah}

Both the Mekbilta and the Sifre also include a Jewish tradition that God first offered the Torah to the nations of the world. There is nothing in the Exodus or Deuteronomy accounts that explicitly says that other people were present at Sinai or that God offered the Torah to other nations, but both the Mekbilta and Sifre imply that other nations at least had an opportunity to receive it.

The Mekbilta claims that God offered the Torah in a desert as a way of making the offer open to other nations, had they wished to comply.
Why was the Torah not given in the land of Israel? In order that the nations of the world should have no excuse for say- ing: Because it was given in Israel's land, therefore we have not accepted it. (Mekilta Bahodesh 5, Lauterbach)

Both the Sifre and the Mekbilta relay the tradition that God offered Torah to the nations of the world and use Genesis to explain why each nation could not have accepted the law. Their ancestors were murders, adulterers and thieves. They could not follow the laws God had given them through Noah, 15 and it was unlikely that they would

15 In Jewish tradition, seven laws were given to the sons of Noah, meaning all of humanity. These included prohibitions against idolatry, cursing God, murder, sexual immorality, theft, eating flesh torn 
be able to uphold the rest of the law either. Consequently, they declined (Sifre \$343; Mekilta Bahodesh 5).

Together these midrashim represent early versions of the Jewish tradition that God offered the Torah to other nations at Sinai. As we will see, later generations of rabbis would connect the miracle of multiple languages at Sinai with the tradition of God offering the Torah to the nations of the world.

\section{The Bavli}

The Babylonian Talmud, often referred to simply as the Bavli, is the longest literary work, approximately 6,00o pages in its standard English editions, produced in late antiquity; it is undoubtedly the crowning achievement of the rabbinic period.

This excerpt from the Bavli is from Shabbat, which belongs to the second order, Moed (Festivals). Shabbat discusses prohibitions of work on the weekly holy day, but as is characteristic of Jewish literature, this section ventures in many different directions, including the greater context of the Sinai experience.

With regard to the revelation at Sinai, R. Johanan said: What is meant by the verse, The Lord giveth the word: They that publish the tidings are a great host? (Psalm 68:I I) - Every single word that went forth from the Omnipotent was split up into seventy languages. The School of

R. Ishmael taught: And like a hammer that breaketh the rock in pieces, just as a hammer is divided into many sparks, so every single word that went forth from the Holy One, blessed be He, split up into seventy

from an animal and a command to establish courts of justice (Babylonian Talmud Sanhedrin 56 a-b). Jubilees 7:28 may be an early reference to these rules. languages. (Babylonian Talmud Shabbat 88b, Freedman)

In this passage, R. Johanan asks what is meant by God's word being proclaimed by a great host, a reference to Psalm 68:I I 'The Lord giveth the word; The women that proclaim the tidings are a great host' (JPS Tanakah I9I7). The answer is found in the tradition that God's voice was heard at Sinai in seventy languages. The number seventy, like four in the Sifre, is symbolic of totality; thus, to say seventy languages is to say all the spoken languages of the world. ${ }^{16}$

\section{Exodus Rabbah}

As previously discussed in the section on the Mekbilta, the midrash concerning Exodus 20:1 8, 'And all the people saw the thunderings', identifies the logical problem of people 'seeing' thunder. However, a much later midrash, ${ }^{17}$ Exodus Rabbah, identifies a different textual aspect from that of the Mekbilta. It focuses on the observation that הקולות ( $b a$ qolot) is plural, 'the voices': God speaks in multiple voices.

It says: And all the people perceived the thunderings (Ex. 20: I 5). Note that it does not say 'the thunder', but 'the thunderings'; wherefore R. Johanan said that God's

16 Incidentally, this exegetical connection between the Sinai narrative and Psalm 68:I I lends further plausibility to Luke's Jewish background and awareness of orally circulating Jewish traditions. Although angels as mediators are not mentioned in the Exodus account of Sinai, Luke references this concept of God's message being delivered by angels in Stephen's speech to the Sanhedrin (Acts 7:38, 53).

17 Exodus Rabbab was probably written/ revised in the eleventh to twelfth centuries (Lehrman I 983: vii). 
voice, as it was uttered, split up into seventy voices, in seventy languages, so that the nations should understand. When each nation heard the Voice in their own vernacular their souls departed, save Israel who heard but who were not hurt. How did the Voice go forth? R. Tanhuma said: The word of the Lord went forth in two aspects, slaying the heathen who would not accept it, but giving life to Israel who accepted the Torah. (Exodus Rabbah 5:9, Lehrman)

Karin Hedner Zetterholm writes that midrash interpretation of 'the voices' needs to be viewed against the background of the early Jewish traditions of God offering the Torah to the nations. Not only did God's voice go out in multiple languages to demonstrate the totality of God's word, but the Torah was expressed in multiple languages to give other nations no excuse for rejecting it (Larsson I999: I35; Zetterholm 201 2: I9).

Exodus Rabbah differs from earlier midrashim in how the gentile nations responded to God's voice. Unlike other narratives, where the gentile nations seem to rationally ponder the offer of the Torah and weigh the consequences of agreeing to its stipulations, here they simply die in the presence of God's voice. In fact, it seems that Israel only survived the encounter with God because they had already accepted the Torah.

The statement, 'When each nation heard the Voice in their own vernacular their souls departed, save Israel who heard but who were not hurt', is reminiscent of Israel's own response to God's demonstration of power. They begged Moses to be a mediator between them and God. 'Speak to us yourself and we will listen. But do not have God speak to us or we will die' (Exodus 20:19). The people in Exodus do not perish from seeing God's voice, but in this midrash, it is suggested that they would have died had not God sent his
Word to save them.

In Exodus Rabbah, the judgement of God falls on those who hear his word and choose to reject it, namely the gentiles, a detail that could not have been lost on a generation surrounded by Muslims and Christians, both of whom claimed to be the true heirs to Abraham's relationship with God. One modern introduction to Midrash Rabbah III Exodus explains that the midrash seems to have been produced in the eleventh and twelfth centuries, 'a period in which Jewish agony reached its height owing to the Crusades' (Lehrman r 983: 3).

These rabbinic writings, beginning with the early midrashim through the Bavli and Exodus Rabbah, demonstrate the prevalence of the Sinai interpretations that include both a voice that appeared as fire and the phenomenon of it also being heard and understood in multiple languages. The tradition of God offering the Torah to the nations is also present, and by the time of Exodus Rabbah the linguistic miracle has been combined with the tradition of God offering the Torah to the nations. And by this time there is no question about the outcome: Israel alone survives the manifestation on Sinai.

\section{Why rabbinic Jews employ Sinai symbols}

As we have already discussed, rabbinic Jews, emerging in the wake of the Temple destruction, perceived themselves as the guardians of sacred scripture. As such, their writings used Sinai symbols to underscore the authority of the Torah in general as well as their authority as interpretative specialists.

The Sifre equated the Torah with fire. Employing this symbol, rabbis made many allegorical connections between Torah and fire. The Torah, like God's voice at Sinai which appeared as fire, came from heaven. The Torah, like fire, brings life to the world. 
Humans can warm themselves by it. But fire is also dangerous, and the Torah if not properly handled can also be dangerous. The Torah is not intended to be handled by those who are not specialists, particularly those of the gentile nations. In fact, for gentiles to touch the Torah improperly is comparable to adultery. Rabbis exegetically connected it to Proverbs, comparing adultery to playing with fire (Prov. 6:27-9) (Fraade r 991: 58).

Fire also served as a boundary marker, separating Israel from the rest of the world. In a Sifre image, God's voice depicted as fire emerges from his mouth, encircling the community of Israel, before returning to his hand, which he used to write the commandments on the stone tablets (Sifre F 399 . I I-I 5). To be a Jew in a rabbinic-centred universe meant to abide within the God-breathed, fiery borders of Torah obedience.

The tradition of multiple languages present at Sinai first appears as an expression of the totality of God's communication (Fraade I99I: 30-I), but later, in combination with the Jewish tradition that God also offered the Torah to other nations, becomes an indictment on gentiles. These nations had an opportunity to accept the Torah and they either rejected it or failed to keep it, a choice that incurs immediate judgement or at least death by exposure to God's voice, according to the late-antique Exodus Rabbah.

Midrash narratives concerning the nations' failure to accept Torah may have been a natural response as rabbinic Judaism established itself amid a growing gentile Christian majority. However, Peter Schäfer points out that this trend may have obtained even in areas where Christians were not in the majority. Jews living in the Zoroastrian Sasanian empire may have also been encouraged to distance themselves from Christians, who were associated with the competing Roman empire. Countering the Christian narrative was one way to do that (Schäfer 2007: I I 7I 9 , I 2 I-2).

To support this theory, Schäfer argues that counter-narratives in the Talmud correspond directly to claims and narratives in the New Testament. They reveal precise knowledge of the New Testament, responding to it as a literary source and 'not to some vague or lost oral tradition'. Schäfer offers the following examples: the parody of Jesus's birth, allusions to Mary Magdalene, stories of Jesus as a Torah teacher, healings and exorcisms in the name of Jesus, and especially, details of his trial and death (Schäfer 2007: I 22-4).

If rabbinic writers, particularly during the period in which the Bavli was being written, were familiar with New Testament writings, then it is likely that they were aware of the narrative of Acts 2 and its use of Sinai symbols. If so, it is possible that the Sinai multivoice tradition could have functioned as a counter-narrative to the tongues miracle in Acts 2. In Acts, the multiple voices initiate an expansion of God's salvation to eventually include gentiles; and by the time the Exodus Rabbah was written, the miracle of God's voice heard in multiple languages explicitly justifies the exclusion of gentile nations from God's relationship with Israel.

As a counter-narrative, the Exodus Rabbab version combines two earlier rabbinic ideas, that God's voice was heard in many languages at Sinai and that the nations refused God's offer of the Torah; and by explicitly connecting these two well-attested rabbinic traditions, the Exodus Rabbab polemically employs Sinai imagery to define Israel in relation to gentile nations and competing religious groups, which also claimed an inheritance in the Sinai relationship. The message is exclusionary: other nations had an opportunity to accept the Torah, especially as they heard God's voice in their own language, and they refused. Thus, the outcome of the 
Sinai revelation is an exclusive relationship between God and Israel.

The implications of Acts 2 are sufficiently contrary to the Exodus Rabbah that the late midrash could be read not only as a combination or progression of rabbinic ideas, but also as a response to Christianity. The message of Acts 2 is that on the day of Pentecost, a day already associated with Sinai, the disciples were filled with God's spirit (the Holy Spirit) and miraculously spoke in other languages which were understood by diaspora Jews. The end result was an expansion of the Jesus Movement, first to the diaspora Jews present in Jerusalem on that day, and by the end of the book of Acts, to gentiles in Palestine and beyond. Thus, the use in Acts 2 of Sinai symbols ultimately communicates the message that the special relationship between God and Israel was now available to gentiles who believe in Jesus, the Jewish Messiah. In the Exodus Rabbah, the use of miraculous multiple languages at Sinai in effect declares that gentile nations had an opportunity to accept the Torah at Sinai and declined it. In contrast to Acts, the fire of God's voice passes judgement on the gentiles and protects those abiding within the boundaries of the Torah.

\section{Conclusion}

The Pentecost narrative found in Acts 2 includes Sinai imagery and reflects Luke's awareness of orally circulating Jewish traditions. Even though Pentecost seems to have been initially celebrated as a harvest festival, there is some indication that by the first century, when Acts was written, it had come to be associated with a commemoration of Sinai. Assuming that Luke was either Jewish or thoroughly steeped in synagogue culture, it seems likely that he used this established connection between Pentecost and his narrative of the Holy Spirit's arrival. His descriptions of wind and fire and God's message being miraculously understood evoked Sinai images from both the Hebrew Bible and Jewish tradition.

Luke used this connection with Sinai to underscore the importance of the Holy Spirit's coming and to place belief in Jesus within the Jewish tradition. For Luke, Jesus was the Messiah who sent the Holy Spirit, in the same way that Moses delivered God's living, fiery Torah. The Acts story begins with Jews, but the narrative projection expands, eventually including gentiles in the relationship begun at Sinai.

For rabbinic writers, the Sinai experience is the fulcrum of Jewish history. The writings of Philo, a diaspora Jew living in the first century, demonstrate that the concept that God's voice visible as fire at Sinai was widespread in Jewish thought long before the first midrash was written down. This visible element of God's voice not only underscores the overwhelming, miraculous nature of the event itself, but it sets up unending metaphors of how God's word is like a fire. This fire purifies, judges and ultimately separates Israel from the rest of the world.

Philo does not include traditions about God's voice being spoken and understood in multiple languages at Sinai, but later rabbinic writings envision such a miracle. The Sifre describes four languages heard at Sinai, while a few centuries the Bavli describes seventy. Both numbers represent the entirety of human language, demonstrating the spatial and linguistic reach of God's message at Sinai. Later, when this concept is combined with the tradition that God offered the Torah to gentile nations, it becomes an indictment on them. According to the Exodus Rabbah, the nations of the world heard God's voice in multiple languages and because they refused, they simply perished in his presence.

Given the lengthy interaction between 
believers in Jesus and other Jewish groups, it seems possible, if not likely, that later rabbinic writers were aware of Luke's Sinai subtext in his Pentecost narrative. If this is the case, then the Exodus Rabbah's combination of the tradition of God offering the Torah to gentiles and God speaking in multiple languages at Sinai could be read as a counternarrative to Acts. Whereas Luke used Sinai symbols to demonstrate an expansion of the Sinai relationship to include gentiles, the Exodus Rabbab seems to use fire and multiple languages to justify the exclusion of gentiles. Like rabbis before them who visualised a Holy Fire surrounding Israel, obedience to the Torah delineated what it meant to be Israel, an interpretation which should not be surprising given the polemic environment of the end millennium.

\section{Theresa Abell Haynes} completed the Religious Roots of Europe MA programme at Lund University in 2020 and plans to continue research in Judaism and early Christianity. She currently lives in Seattle, Washington.

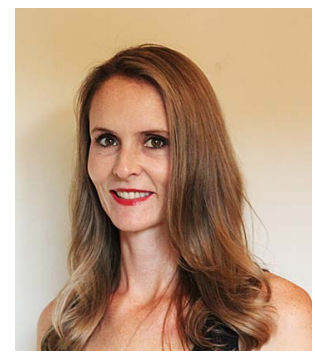

\section{Bibliography}

\section{Primary sources}

Exodus Rabbah, in The Midrash Rabbah, vol. 3, trans. S. M. Lehrman, ed. Rabbi Dr H. Freedman and Maurice Simon (London: Soncino Press, I 983), 86-7.

The Hebrew-English Edition of the Babylonian Talmud: Shabbath, trans. Rabbi Dr H. Freedman (London: Soncino Press, I 987).

Holy Bible, New International Version (Grand Rapids, MI: Zondervan Publishing House, I 984).

JPS Tanakh I9 I7. The Holy Scriptures according to the Masoretic Text (Jewish Publication Society's English version of the Bible), $<$ https://biblehub.com/jps/> (accessed 7.5.202I).
Mekbilta de-Rabbi Ishmael: A Critical Edition on the Basis of the Manuscripts and Early Editions with an English Translation, Introduction and Notes, vol. 2, trans. Jacob Lauterbach (Philadelphia: Jewish Publication Society of America, I 949).

Philo, On the Decalogue, ed. and trans. F. H. Colson. Loeb Classical Library, 320 (Cambridge, MA: Harvard University Press, I937).

Sifre to Deuteronomy, trans. Steven D. Fraade in From Tradition to Commentary: Torah and its Interpretation in the Midrash Sifre to Deuteronomy (Albany: State University of New York, I99I).

\section{Secondary literature}

Becker, Adam, and Annette Yoshiko Reed (eds.). 2007. The Ways that Never Parted (Minneapolis, MN: Fortress Press, 2007).

Ben-Eliyahu, Eyal, Yehuda Cohen, and Fergus Millar (eds.). 20I3. Handbook of Jewish Literature from Late Antiquity, I 35-700 CE (Oxford University Press).

Bruce, F. F. I 990. The Acts of the Apostles: Greek Text with Introduction and Commentary (Grand Rapids, MI: Wm. B. Eerdmans Publishing Company).

Davis, Jud. 2009. 'Acts 2 and the Old Testament: the Pentecost Event in Light of Sinai, Babel and the Table of Nations', Chriswell Theological Review 7(I): 29-48.

Fraade, Steven D. I991. From Tradition to Commentary: Torah and its Interpretation in the Midrash Sifre to Deuteronomy (Albany: State University of New York).

Hayes, Christine. 20 I I. The Emergence of Judaism: Classical Traditions in Contemporary Perspective (Minneapolis, MN: Fortress Press).

Jervell, Jacob. 1 996. New Testament Theology: The Theology of the Acts of the Apostles (Cambridge University Press).

Keener, Craig S. 201 2. Acts: An Exegetical Commentary (Grand Rapids, MI: Baker Academic).

Kugel, James L. I 997. The Bible as it Was (Cambridge, MA: Belknap Press of Harvard University Press).

Larsson, Göran. I 999. Bound for Freedom: The Book of Exodus in Jewish and Christian Traditions (Peabody, MA: Hendrickson Publishers).

Lehrman, S. M. I983. 'Introduction' to Exodus Rabbah, in The Midrash Rabbah, vol. 3, trans. S. M. Lehrman, ed. Rabbi Dr H. Freedman 
and Maurice Simon (London: Soncino Press), vii-viii.

Oliver, Isaac Wilk. 20 2. 'Torah Praxis after 70 C.E.', Ph.D. diss., University of Michigan.

Park, Sejin. 2008. Pentecost and Sinai: The Festival of Weeks as a Celebration of the Sinai Event (New York: T\&T Clark International).

Schäfer, Peter. 2007. Jesus in the Talmud (Princeton University).

VanderKam, James C. 2002. 'Covenant and Pentecost', Calvin Theological Journal 37: 239-54.

Zetterholm, Karin Hedner. 201 2. Jewish Interpretation of the Bible: Ancient and Contemporary (Minneapolis, MN: Augsburg Fortress). 